\title{
AN ACTUAL CASE FOR REFLECTION OF PROBLEMS IN INTERNATIONAL (POLITICAL AND MILITARY) RELATIONS ON TOURISM SECTOR: “TURKEY-RUSSIAN FEDERATION 2015 CRISIS” AND QUANTITATIVE REFLECTIONS ON TURKEY TOURISM
}

DOI: http://dx.doi.org/10.18509/GBP.2016.38

UDC: $338.48(560): 327(470)$

\author{
Prof. Dr. Serhat ZAMAN \\ Atatürk University- Faculty of Education, \\ Department of Geography Education, Erzurum/TURKEY
}

\begin{abstract}
Tourism is one of the sectors composed of versatile and complex relations, whose response and influence level is the most powerful one. One or two other sectors may barely have the intense interaction apart from tourism. It is possible to say that as a sector, absence of tourism cannot be bearable in today's world. This is the case for countries which both send and welcome tourists; because in most of the countries which send tourist, travelling and tourism have become a requirement; it is perceived as a primary requirement that cannot be postponed. On the other hand, in countries which accept considerable number of tourists, this sector has become indispensable due to its reproductive effects. Therefore sustainability is quite an important subject for this group of countries. However, everyone accepts that tourism is one of the fragile and sensitive sectors by nature. In spite of that, tourism is one of the most skillful sectors in overcoming problems and directing towards new expansions. Apart from marginal types of tourism, processes such as positive international relations and peace environment have always influenced tourism in positive way. However, global economic crises, regional instability, wars, political tensions have had negative effect. In this study, it will be analyzed quantitatively whether tension experienced between Turkey and Russian Federation in November 2015 has reflected on tourism or not.
\end{abstract}

Keywords: Turkey, Russian Federation, Tourism, Tourism geography, International relations

\section{INTRODUCTION}

Tourism is one of the most important fields which help countries to interact with each other. Especially after the World War II, tourism showed a rapid development and it has become a component of globalisation, maybe the most important one. The development it went thorough captivated not only the individuals who met it but also the countries. Nearly all countries which either earn profits or lose foreign currency due to tourism approach this sector from positive perspectives apart from a few exceptions in the past. It is possible to say similar things regarding individuals because increased urbanization and being urbanized caused by urbanization have established a close relation with tourism. Today, tourism has become a need which can not be delayed for most of them. Travelling and joining international tourism have become a routine for the citizens of many countries 
who do not have any problems related to their health and economic conditions. Due to these reasons, tourism still continues to be one of the fastest growing sectors of the world and its participants have been increasing more in number than ever before. [1]

Tourism is a system which is composed of multidimensional relations. Due to its structure, it both affects and is affected. With its multiplying effects, it is possible to see tourism and a branch of an activity which interacts with tourism in any field in life. State economies which are mainly dominated by tourism in the world are not few in number. In addition to this, there are some countries in the world which do not rely on tourism but tourism makes itself felt in economic fields. Tourism is not a subject which can be explained with only its economic dimensions.

Besides economic effects of tourism, it has got cultural, social, environmental, political, and psychological effects. Thus, it is possible to state that it is one of the most effective tools of our century. Tourism has local, regional, national and increasingly international importance. [2] By year 2015, the number of tourists involved in tourism has reached 1.2 billion. The contribution of this sector in the total services sector in the world is about $30 \%$ and its share in the world export market is $6 \%$.

It is the biggest sector after energy, chemistry, and food sector. Tourism surged ahead of a giant sector like automotive industry. [3] Tourism has its unique structure just like every sector. Tourism's most obvious feature is its fragile structure. Tourism sector interacts nearly with every sector and benefits from them and also it is affected positively or negatively with the events and processes occurring at global, national, and local scale. This study examines whether the "downing jet crisis" between Turkey and Russian Federation in 2015 had qualitative reflections on Turkish tourism or not. Within this context, the qualitative data were scanned and evaluations and recommendations were made considering this data. As known, Turkey is one of the countries that host many tourists. Turkey has become one of the ten countries which has been visited over the last decade, so Turkey has proved its ambition and strength. Thus, Turkey was ranked 6th in this field in the world in 2015. If it sustains its performance over the next decade, it can move up in the list because Turkey has lots of potential tourist attractions which have not been introduced into tourism both culturally and naturally yet. However, this performance is not only about using this potential but also at the same time it is about managing positive and negative factors which can have an effect on tourism. Turkey's experience up till now reveals that Turkey has done a good job.

Table 1. Most visited countries in the World [4]

\begin{tabular}{|c|c|c|}
\hline Rank & Country & International visitors (million) \\
\hline 1 & France & 83,7 \\
\hline 2 & USA & 74,8 \\
\hline 3 & Spain & 65,0 \\
\hline 4 & China & 55,6 \\
\hline 5 & Italy & 48,6 \\
\hline 6 & Turkey & 39,8 \\
\hline 7 & Germany & 33,0 \\
\hline 8 & United Kingdom & 32,6 \\
\hline 9 & Russia Fed. & 29,8 \\
\hline 10 & Mexico & 29,1 \\
\hline
\end{tabular}

Major tourism destinations in the world have been generally characterized with one or a few types of tourism like Egypt with historical sites, Greek Islands and Ancient Greece with their works of architecture, Austria and Switzerland with their winter tourism, the 
Caribbean with their sea and yacht tourism and so on. Turkey's tourism has triggering types of tourism, too such as coastal tourism, cultural tourism, belief tourism, thermal tourism, sports tourism and so on. These are the strengths of Turkey which make it so special when compared to other tourist destinations. In other words, Turkey has a wide range of tourism products. In parallel with this, tourism markets which prefer Turkey have been varied. That's to say, Turkey is not a tourism destination which depends on only one market or lives on single source. Any social, economic, and political problems experienced in any of the countries whose citizens visit Turkey as tourists reflect on Turkey directly. However, because Turkey is a tourism country which lives on different sources and appeals to different markets, it can tolerate the demand instability in one of the countries where tourists come from. For example, After the Gaza crisis with Israel, the number of Israeli tourists coming to Turkey decreased; on the other hand, the number of Arab tourists visiting Turkey increased.

Table 2. Countries that send most tourist in Turkey (2015) [5]

\begin{tabular}{|c|c|c|c|}
\hline Rank & Countries & Tourist (million) & $\%$ \\
\hline 1 & Germany & 5580792 & 15.0 \\
\hline 2 & Russia & 3649003 & 10.07 \\
\hline 3 & England & 2512139 & 6.93 \\
\hline 4 & Georgia & 1911832 & 5.27 \\
\hline 5 & Bulgaria & 1821480 & 5.03 \\
\hline 6 & Iran & 1700385 & 4.69 \\
\hline 7 & Netherland & 1232487 & 3.40 \\
\hline 8 & Iraq & 1094144 & 3.02 \\
\hline 9 & France & 847259 & 2.34 \\
\hline 10 & USA & 798787 & 2.20 \\
\hline
\end{tabular}

\section{PLACE OF RUSSIAN FEDERATION IN TURKEY TOURISM}

Turkey hosted visitors that settled in many continents and countries in the world last year. However, some regions are responsible for a large proportion of total number. For example, $53 \%$ of the visitors came from Europe and OECD countries. Common Wealth of Independent States (CIS) accounted to $22.5 \%$ after Europe. The visitors from Asian countries make up $16 \%$, from African countries $2.4 \%$ and from the USA $0.7 \%$.

Table 3. The distribution of tourists in Turkey according to the regions they come from [6]

\begin{tabular}{|c|l|c|}
\hline Rank & Regions & $\%$ \\
\hline 1 & Europe and OECD & 53,01 \\
\hline 2 & CIS (Commonwealth of Independent States) & 22,58 \\
\hline 3 & Asia & 16,60 \\
\hline 4 & Africa & 2,39 \\
\hline 5 & America & 0,77 \\
\hline 6 & Others & 4,65 \\
\hline
\end{tabular}

$48 \%$ of the tourists visiting Turkey come from only 7 countries. These are Germany, Russian Federation, England, Georgia, Bulgaria, Iran, and the Netherlands, respectively. Out of these seven countries, three of them are Turkey's border neighbours. Over the last decade, the countries sending tourists to Turkey have not changed. These countries are Germany and Russian Federation. These two countries are the countries which send a great majority of tourists not only to Turkey but also to the other tourism countries in the world. Turkey, due to its geographical location, receive tourist from surrounding regions 
and countries. Because Turkey is located at the crossroads of some regions like Europe, Eurasia, Africa, and the Middle East, it provides advantages regarding tourism. It is possible to reach Turkey from European countries and Russia with trips which are not too long. Being close to Europe, the continent which sends the largest number of tourists in the world, is a big advantage for Turkey. In addition to this, it is possible to say similar things for Russia which is a country that has a big share in tourism propensity. [7] Russian Federation has been one of the most important tourism markets for tourism in Turkey for nearly 20 years. In the meantime, Russia's share in Turkish tourism began to surpass Germany which was Turkey's biggest market without question. It can be clearly understood from the numerical values. Russian tourists generally visit Turkey to take part in tourism activities based on sea and beach in the southwest of Turkey, so they have an important role in Turkey's tourism performance in recent years. Although they rarely visit the other tourist attractions in Turkey apart from the hotels located in the coastal regions, Russian tourists and the economy they create become indispensable for some major tourism fields. Even some tourism fields are designed and equipped considering Russian tourists in Turkey. Thousands of people speaking Russian and most of whom come from Turkic Republics were recruited in some tourism centres, mainly in Antalya. Unquestionably, Russian tourists mainly prefer Antalya and its surroundings in Turkey. Antalya is a centre of attraction not only for Russians but also for millions of tourists from other nationalities. Germans made up the largest number of tourist groups which Antalya hosted for long years. However, in recent years the number of Russian tourists visiting Antalya approached Germans and even surpassed them in some years. For example, 3.5 million Russian tourists visited Antalya in 2014. This value makes up $30 \%$ of all the tourists vacationing in Antalya. In the same year, German tourists ranked second (26\%), following the Russians. The number of Russian tourists decreased dramatically in 2015. The number of Russian tourists visiting Antalya in 2015 decreased to 2.8 millions, a decrease of $26 \%$. 18\% drop was observed between 2014 and 2015. On the other hand, in the same period, an increase of $10 \%$ with Ukrainian tourists and $8 \%$ with American tourists was observed. The number of German tourists increased 8\%, Hungarian tourists $37 \%$, Israeli tourists $15 \%$, and Romanian tourists $16 \%$. In the mentioned time period, Russian Federation was not the only country with a decreased in the number of tourists. A dramatic decrease was also observed with other countries like France (37\%), Sweden (10\%), Norway (15\%), Austria (13\%), and Italy (13\%) compared to the previous year. Therefore, Antalya an important tourism region, hosted nearly 12 million tourists last year and 2.8 millions of these tourists were the Russian. Despite the dramatic decrease in the number of Russian tourists, they still top the ranking both numerically and proportionally. Russian tourists travel to Istanbul, following Antalya. 3.9\% of the tourists visiting Istanbul were from Russian Federation in 2015 (5\% in 2014). In that period Istanbul hosted nearly 12 million tourists. [8] Russian market for Istanbul is not as vital as it is for Antalya. Moreover, it is possible to understand this from the proportional values.

Arabic countries have become one of the important markets for tourism in Turkey. For example, while 1.6 million Arabic tourists visited Istanbul, one of the two cities which attract the largest number of tourists, in 2013, this number amounted to 2.5 million tourists. This number makes up $20 \%$ of the total tourists travelling to Istanbul. In the same period, the number of tourists travelling to Istanbul from Russian Federation was 573.000 in 2013 and 589.000 in 2014 but in 2015 a sharp decrease was observed with the number of Russian tourists in Istanbul and the number decreased to 489.000. This regression was not due to the downing jet crisis, the subject of our paper, but the war which caused a 
crisis between Russia and Ukraine was considered to be responsible for this regression because the jet crisis between Turkey and Russia broke out through the end of 2015. The months after the crisis are the seasonal period when the tourist arrivals decline in number. It is so clear that the shooting down a Russian jet in last months of 2015 has some negative effects on Turkish tourism. In order to state these effects numerically, it is important that the last month of 2015 and the data of 2016 must be compared to previous years. As this study was carried out at the beginning of 2016, an evaluation was made considering a very short period without regarding a long term qualitative data. For instance, the number of tourists visiting Turkey declined dramatically compared to the same month of the year in December, 2015, the first month after the jet crisis. In fact, the decline in the number of Russian tourists visiting Turkey started in last months of 2014 and the decrease continued within the year of 2015. Thus, the number of Russian tourists visiting Turkey decreased from 4.4 million in 2014 to 3.6 million in 2015 . We have the belief that the drastic decrease in the number of Russian tourists in 2015 is thought not to be the result of relationship between two the countries but this decrease is due to the economic recession Russia experienced after it invaded some regions of Ukraine.

In addition to this, despite economic decline in Russia and the jet crisis with Turkey, Russian tourists still vacation in Turkey. Although Russian government's recommendation that Russian citizens do not visit Turkey at all has an important effect, some Russian still buy holiday individually and continue to travel to Turkey.

Table 4. Distribution of Russian tourists visiting Turkey according to the months and years [9]

\begin{tabular}{|c|c|c|c|c|}
\hline Months & $\mathbf{2 0 1 0}$ & $\mathbf{2 0 1 3}$ & $\mathbf{2 0 1 4}$ & $\mathbf{2 0 1 5}$ \\
\hline January & 36638 & 57616 & 65412 & 51058 \\
\hline February & 39715 & 62910 & 60593 & 41444 \\
\hline March & 43342 & 74861 & 81868 & 58338 \\
\hline April & 104672 & 200740 & 215761 & 149879 \\
\hline May & 454369 & 608716 & 694886 & 501196 \\
\hline June & 578527 & 690287 & 805291 & 652703 \\
\hline July & 535722 & 674353 & 805631 & 686256 \\
\hline August & 547059 & 735386 & 776494 & 638469 \\
\hline September & 478019 & 710031 & 637768 & 528960 \\
\hline October & 178497 & 316187 & 224430 & 229125 \\
\hline November & 65417 & 77210 & 62961 & 86090 \\
\hline December & 45066 & 61009 & 47954 & 25485 \\
\hline Total & $\mathbf{3 1 0 7 0 4 3}$ & $\mathbf{4 2 6 9 3 0 6}$ & $\mathbf{4 4 7 9 0 4 9}$ & $\mathbf{3 6 4 9 0 0 3}$ \\
\hline
\end{tabular}

\section{CONCLUSION AND DISCUSSION}

The tension which began between Turkey and Russia when Turkey shot down a Russian jet in November is still heating up in 2016 because Russia still stray into Turkish airspace with new violation at the end of January, 2016. During the Soviet Union period, the two countries were border neighbours with each other and after the collapse of the union, they established quite good relations in social, cultural, economic, and political fields. There are very strong relations between the two countries regarding the fields of energy, agricultural products, some industrials branches, and tourism. Fifteen cooperation agreements were signed between 1992 and 1996. [10] The sustainability of these relationships is directly proportionate to the course of the intergovernmental political relations. As known, not only tourism but also other economic and cultural cooperation live on positive political relations. The tension called as the jet crisis undoubtedly affected 
the sectors mentioned above directly. The crisis had distinct effects on both countries, especially in economic field. Not only Turkey but also Russian Federation were affected because the history of relation between the two countries continued for 500 years and these relations had deep impacts regarding political, economic, and cultural fields. [11] Besides the historical depth of the relations, there are strong connections between Turkey and Russia. For example, a considerable number of Russian expats reside in Turkey, especially in Antalya and its surroundings. Moreover, a large number of them (87\%) work in tourism sector. [12] The tension between the two countries still continues to escalate in 2016. Thus, the year 2016 seems to continue with negative values in many sectors, but mainly in tourism sector. Because this crisis has possible effects on Turkish tourism, we can list some evaluations like that:

Because this crisis occurs with Russia, one of the two countries which Turkey sells most of its tourism products, it will certainly have an effect on Turkey. However, Turkey is not a country of tourism with a small market which host tourists from a few countries in the world. Turkey has a large potential market to compensate this. As one of the experienced tourism countries in the world, Turkey has an experience to manage such a crisis. This tension which we hope to turn to normal in a very short time can be regarded as a crisis experience and an advantage for Turkey to deal with it. Thus, it is known that Turkey has been looking for new markets for a long time and it is after involving countries like China, the USA, and Gulf countries, and India in tourism market. The numbers demonstrate that Turkey is partially successful with it.

In the first months of 2016, the institutions which organize tourism in private and public sector in Turkey act as if no Russian tourists will visit Turkey. Most probably, despite the suggestions of Russian government, thousands of tourists will travel to Turkey without taking these into consideration and via acting independently. However, it is predicted that the number of tourists will not reach the previous years. Turkey is in search of going towards from quantity to quality so this crisis can be a turning point. It is most likely that fewer tourists will visit Turkey next year. But focusing on the targets related to quality values instead of qualitative values in tourism might speed up this search via this crisis because the complaints from mass tourism and package tours have reached its peak because there are countries in the world which have fewer number of tourists than Turkey but gain more tourism revenue than Turkey. These examples cause motivation for Turkey to focus on new targets.

In conclusion, Turkey, one of the most visited countries in the world, has had many experiences which would have a negative effect on tourism over the last two decades. Due to its location, the conflicts and wars in the neighbouring countries and instable regions had a negative effect on tourist preferences towards Turkey. Gulf War, invasion of Iraq, War between Russia and Georgia, security problems originating from Syria are only some of them. In other words, you will see when you look at the world map that Turkey is surrounded with neighbouring regions where there are political problems and unrest. In spite of these big problems, Turkey has broken records in tourism and has had a top place in the World Tourism Rankings. In addition to this, Turkey has fought with bird flu for some time and also Turkey has been fighting with the activities of separatist terrorist organization in the southeast. The two terror attacks which occurred only in 2015 are like a summary of these long years. As it can be remembered, one of them is Ankara bombing, the bloodiest and the deadliest terror attack in Turkey's history and the other one is a terror attack which aimed at a group of German visitors in the Sultanahmet area of Istanbul. It is so clear that these terror attacks have negative effects on Turkey's 
tourism. On the other hand, Turkey is not the only tourism country which is faced with such problems. Even France, world's leading tourist nation, faces terrorist attacks. The leading countries of tourism know the nature and fragile structure of tourism very well. That's why they have plan B against the crisis

\section{REFERENCES}

[1] Timothy, J, D., Tourism and Political Boundaries. Routledge, p:1, 2011.

[2] Williams, S., Tourism Geography a New Synthesis. Routledge, p:1, 2009.

[3] Url-1 http://www2.unwto.org/ Retrived date 02.02.2016

[4] Url-2 http://yigm.kulturturizm.gov.tr/. Retrieved date: 03.02.2016

[5] Url-3 http://yigm.kulturturizm.gov.tr/ Retrieved date: 01.02.2016

[6] Url-4 http://yigm.kulturturizm.gov.tr/ Retrieved date: 03.02.2016

[7] Doğanay, H., Zaman, S., Türkiye Turizm Coğrafyası. Pegem Akademi, P:61, 2013.

[8] Url-5 http://www.istanbulkulturturizm.gov.tr/tr/turizm-istatistik Retrieved date: 03.02.2016

[9] Url-6http://yigm.kulturturizm.gov.tr/TR,9854/sinir-giris-cikis-istatistikleri.html Retrieved date: 03.02.2016

[10] Özbay, F., The Relations between Turkey and Russia in the 2000's. Perceptions, 16.3, pp:69-92, 2011.

[11] Özdal, H., Özertem, H, S., Has, K., Demirtepe, M.T., Türkiye-Rusya İlişkileri Rekabetten Çok Yönlü İşbirliğine. USAK Avrasya Araştırmaları Merkezi, Rapor No:1306, p: 2013.

[12] Deniz, A., Özgür, E.M., Rusya'dan Türkiye'ye Ulusaşırı Göç: Antalya'daki Rus Göçmenler. (Transnational Migration from Russia to Turkey: Russian Migrants in Antalya) Ege Coğrafya Dergisi, (Aegean Geographical Journal) 19-1, 13-30, 2010. 